\title{
Dinoflagellate cyst stratigraphy of the Barremian to Albian, Lower Cretaceous, North-East Greenland - a summary
}

\author{
Henrik Nohr-Hansen
}

As part of studies of the onshore hydrocarbon potential in East Greenland undertaken by the Geological Survey of Greenland (GGU), a project was initiated with the purpose of describing the dinoflagellate cyst stratigraphy of the Lower Cretaceous succession in East Greenland $\left(72^{\circ}-\right.$ $76^{\circ} \mathrm{N}$ ) and correlating the exposed sections throughout the region (Nøhr-Hansen, 1993).

Based on the rather sporadic occurrence of macrofossils the Lower Cretaceous sediments of East Greenland were previously dated as Aptian to Albian (Spath, 1946; Maync, 1949; Donovan, 1953, 1955, 1957). Maync (1949) reported the total exposed thickness of the 'Aptian-Albian series' to be more than $2000 \mathrm{~m}$, whereas Surlyk (1990) noted that the Lower Cretaceous shale succession reached a cumulative thickness of $1000 \mathrm{~m}$. Furthermore, Donovan (1972) reported that Hauterivian and Barremian sediments were unknown in East Greenland.

Dinoflagellate cysts recorded from 40 sections throughout the region have now dated the Lower Cretaceous sequence as Barremian to Albian, and correlation of sections yields a cumulative thickness of approximately $1500 \mathrm{~m}$ (Nøhr-Hansen, 1993) (Figs 1-3).

\section{General stratigraphy}

The Lower Cretaceous mudstone succession of East Greenland was apparently deposited in a storm-dominated muddy inner shelf environment (Stemmerik et al., 1993).

The Barremian deposits are represented by approximately $140 \mathrm{~m}$ of poorly laminated, silty shales with abundant kidney-shaped calcareous concretions. These shales are erosively overlain by a thin calcareous sandstone of early Aptian age, followed by $80 \mathrm{~m}$ to $220 \mathrm{~m}$ of sandy shales of Aptian age. Following a presumed depositional break in the upper Aptian/lower Albian, depositional rates increased considerably and $1120 \mathrm{~m}$ of shales and finegrained sandstones with several coarsening-upward cycles were deposited during the Albian. A hiatus between the lower and middle Albian and a second hiatus between the middle and upper Albian is suggested by the fact that several dinoflagellate cyst species have their last or first occurrences at these levels (Fig. 2).
The Barremian-Albian succession unconformably overlies sediments of Late Permian to Early Cretaceous age (Stemmerik et al., 1993). During deposition of the shales an increase in subsidence rate took place, possibly as-

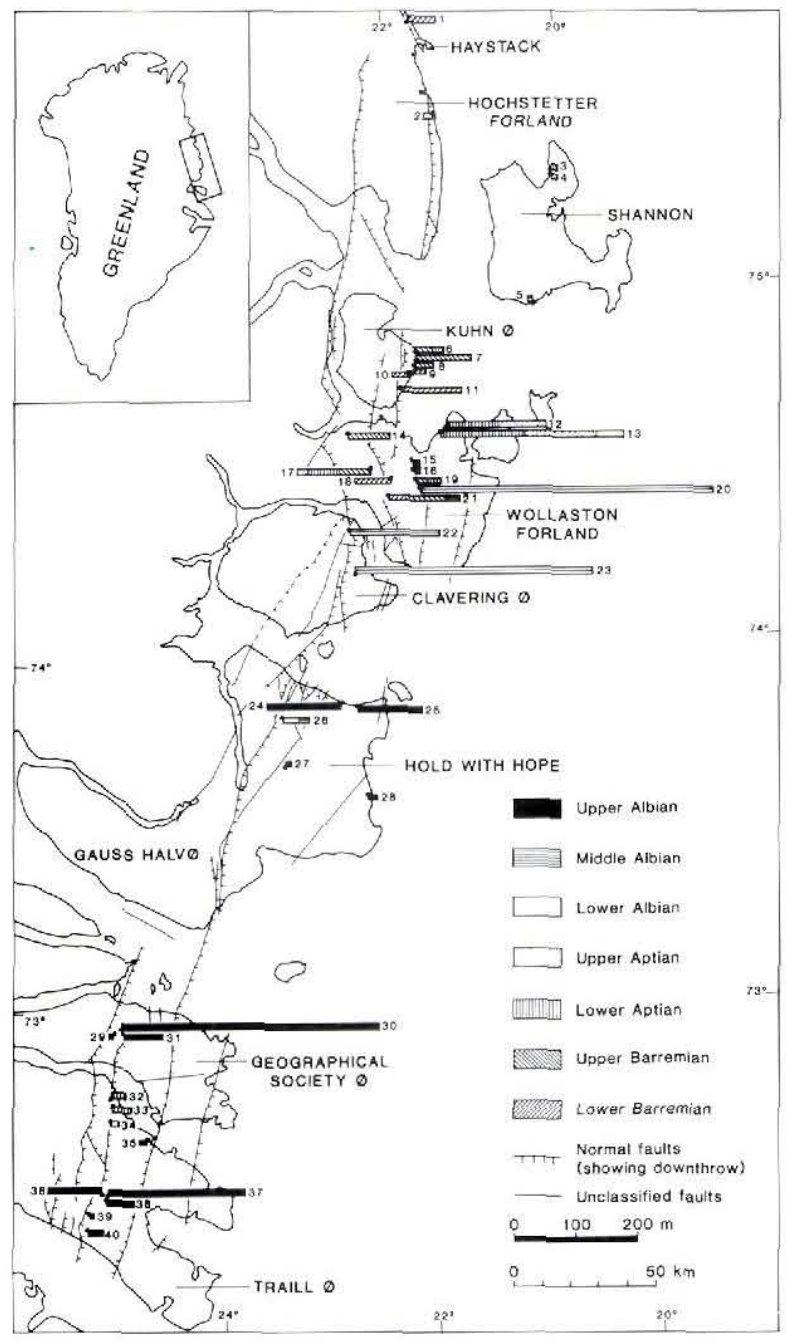

Fig. 1. Location of 40 examined Lower Cretaceous sections in East Greenland that yielded dinoflagellate cysts. The length of the bars represent the thicknesses of the sections and the hatching illustrates the stages represented in each section, as determined on the basis of the dinoflagellate cyst assemblages. 


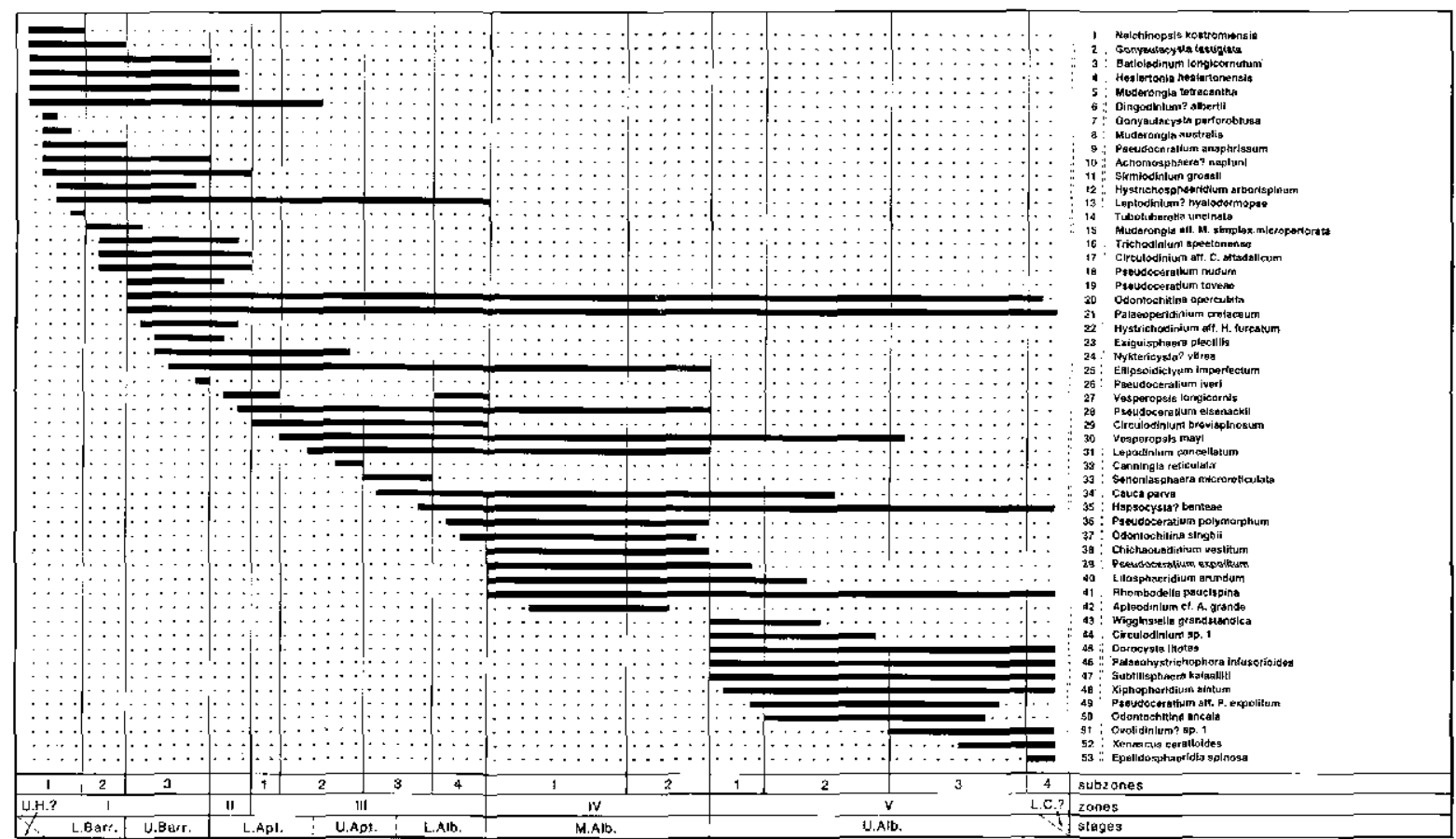

Fig. 2. Total stratigraphical range of 53 age diagnostic dinoflagellate cyst species selected from the 176 recorded species of the Lower Cretaceous succession of East Greenland.

sociated with an overall sea-level rise initiated during the latest Hauterivian? or early Barremian and culminating in the Albian (Nohr-Hansen, 1993; Stemmerik et al., 1993).

\section{Composition of the organic material}

Well preserved dinoflagellate cysts dominate the palynomorph assemblages throughout the succession; 176 dinoflagellate cyst species were recorded in the present study. Saccate pollen and other miospores occur throughout in low number's, while acritarchs, other algae and miscellaneous palynomorphs are rare.

The organic material is dominated by palynomorphs and by brownish to black woody material; amorphous organic material constitutes a minor part. No clear stratigraphical or regional variation in composition of the organic material was observed.

The organic material is thermally immature to mature with respect to oil generation. The thermal alteration index (TAI) is -2 to +3 . Chemical analyses of the organic matter yielded total organic carbon (TOC) values of 0.5 to $5.0 \mathrm{wt}$. \% . Whereas the $S_{2}$ values are too low $(0.1$ to $1.0 \mathrm{mg} \mathrm{HC} / \mathrm{g}$ rock) to indicate polential as source-rocks for oil.

\section{Diversity}

The diversity of dinollagellate cyst species, as measured by the number of recorded species per sample, varies from 9 to 46 (Nøhr-Hansen, 1993). The diversity is relatively high (18-30 species) in samples of earliest Barremian age. The highest diversity (more than 40 species) is recorded in samples of latest Barremian to earljest Aptian agc, and this is followed by a low diversity interval (9-25 species) of late early Aptian to early Albian age. In the middle Albian the diversity again increases ( $30-40$ species). Finally, in the upper part of the studied succession assigned a late Albian age the diversity is again relatively low and stratigraphically uniform ( $15-2.5$ species).

\section{Dominant and frequent species}

References to the species mentioned below and listed in Figure 2 are described in Lentin \& Williams (1989) and in Nøhr-Hansen (1993).

Oligosphaeridium? asterigerum is common in the lowermost Barremian sediments, whereas Muderongia australis dominates a thin zone in the same interval. Pseudoceratium anaphrissum and Muderongia atf. M. simplex microperforata are common to very abundant in the higher parts 


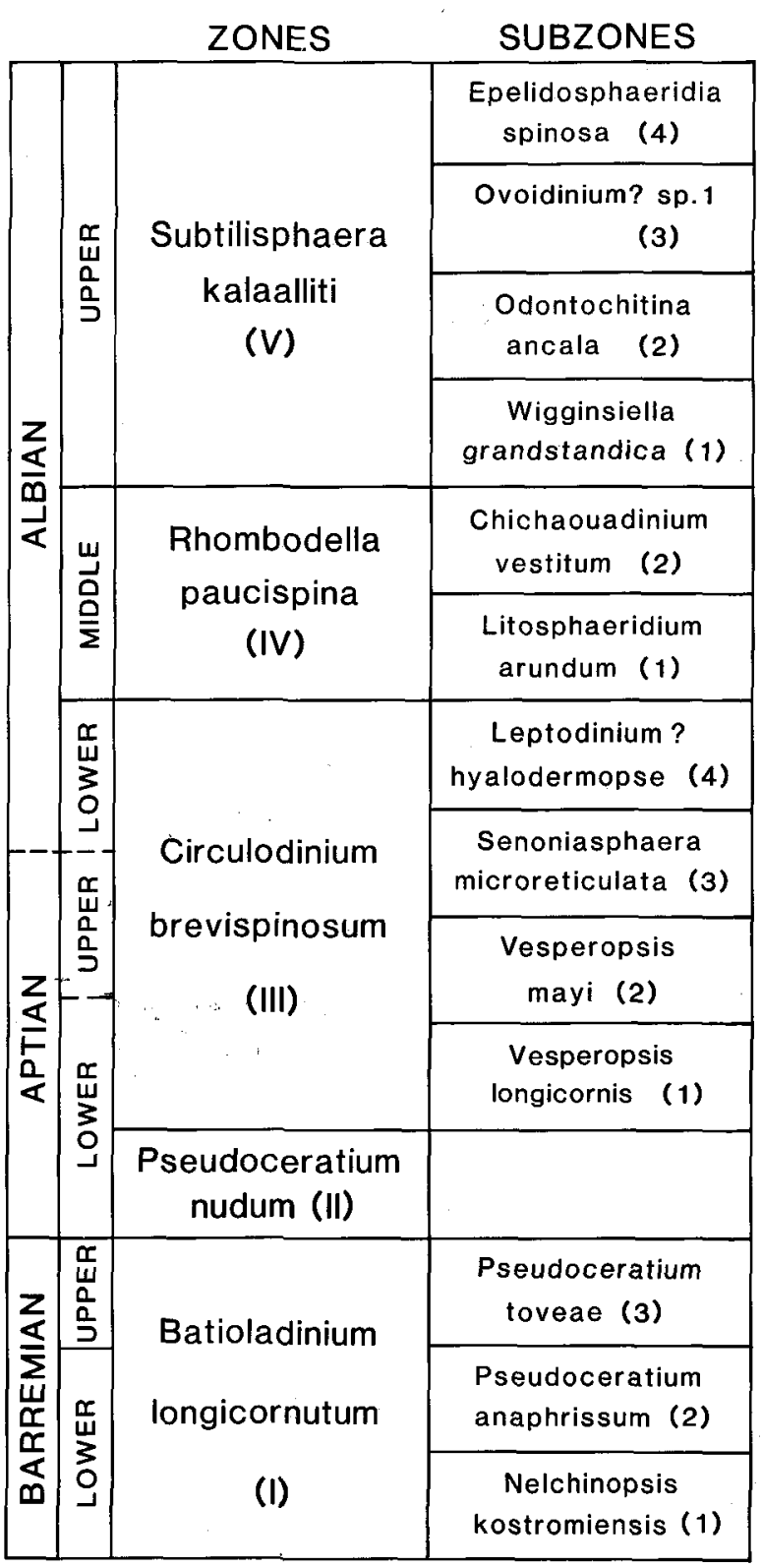

Fig. 3. Dinoflagellate cyst zonation for the Barremian to Albanian in East Greenland $\left(72^{\circ}-76^{\circ} \mathrm{N}\right)$.

of the lower Barremian. Pseudoceratium toveae (Fig. $4 \mathrm{~g}$ ) and Circulodinium aff. C. attadalicum are common in the upper Barremian, whereas Cribroperidinium muderongense is very abundant in a restricted interval in the uppermost Barremian.

Circulodinium aff. C. attadalicum is very abundant in the lowermost Aptian whereas Vesperopsis longicornis and Chlamydophorella trabeculosa are common to very abundant in sediments considered to belong to a higher level of the lower Aptian. Oligosphaeridium complex is very abundant in the higher parts of the lower Aptian to the lower parts of the upper Aptian. Senoniasphaera microreticulata is very common in the uppermost Aptian to the lowermost Albian.

Circulodinium brevispinosum and Vesperopsis longicornis are common to abundant in the lower Albian. Circulodinium sp. 1 is very abundant in the lowermost parts of the upper Albian. Rhombodella paucispinosa and Subtilisphaera kalaalliti (Fig. 4j) dominate the assemblages in the middle and the uppermost Albian; Ovoidinium? sp. 1 (Figs $4 \mathrm{~h} \& \mathrm{i}$ ) is quite common in the upper part of this interval.

Chlamydophorella trabeculosa, Oligosphaeridium complex and Spiniferites spp. are common to abundant throughout the major part of the studied sequences. Odontochitina operculata, Palaeoperidinium cretaceum and Sentusidinium sp. 1 are common to abundant in most of the samples tentatively considered to belong to the upper Barremian to upper Albian.

\section{Provincialism}

The dinoflagellate cyst assemblages from East Greenland seem to be almost identical to assemblages from offshore Norway and show similarities with assemblages previously described from north-west Europe and Canada. However, it is remarkable that some of the assemblage

Fig. 4. Examples of stratigraphically important dinoflagellate cyst from Lower Cretaceous of East Greenland.

a. Hapsocysta? benteae holotype, 500x, section 21; GGU 342240-4, 10.0-140.0; MGUH 21988

b. Hystrichosphaeridium arborispinum 500×, section 7; GGU 342081-4, 17.4-157.1; MGUH 21807

c. Leptodinium cancellatum $500 \times$, section 20; GGU $342176-4$, 11.3-150.2; MGUH 21825

d. Nelchinopsis kostromiensis 500×, section 10; GGU 342092-4, 21.9-144.8; MGUH 21843

e. Nyktericysta? vitrea 500×, section 17; GGU 342169-4, 17.1153.2; MGUH 21850

f. Pseudoceratium iveri holotype 500x, section 17; GGU 342166-5, 16.7-146.0; MGUH 21924

g. Pseudoceratium toveae holotype 500x, section 1; GGU 360371-3, 15.3-132.0; MGUH 21948

h. Ovoidinium? sp. $1500 \times$, section 30 ; GGU $324615-7,19.0$ 127.8; MGUH 21970

i. Ovoidinium? sp. $1700 \times$, section 24 ; GGU $346451-4,5.6-143.0$; MGUH 21972

j. Subtilisphaera kalaalliti holotype $730 \times$, section 30 ; GGU 324622-3, 23.0-138.4; MGUH 21992

k. Tubotuberella uncinata 500×, section 9; GGU 342069-4, 5.6147.8; MGUH 22011

1. Wigginsiella grandstandica $500 \times$, section 29; GGU 324599-4, 3.5-124.9

All scale bars represent $20 \mu$. 

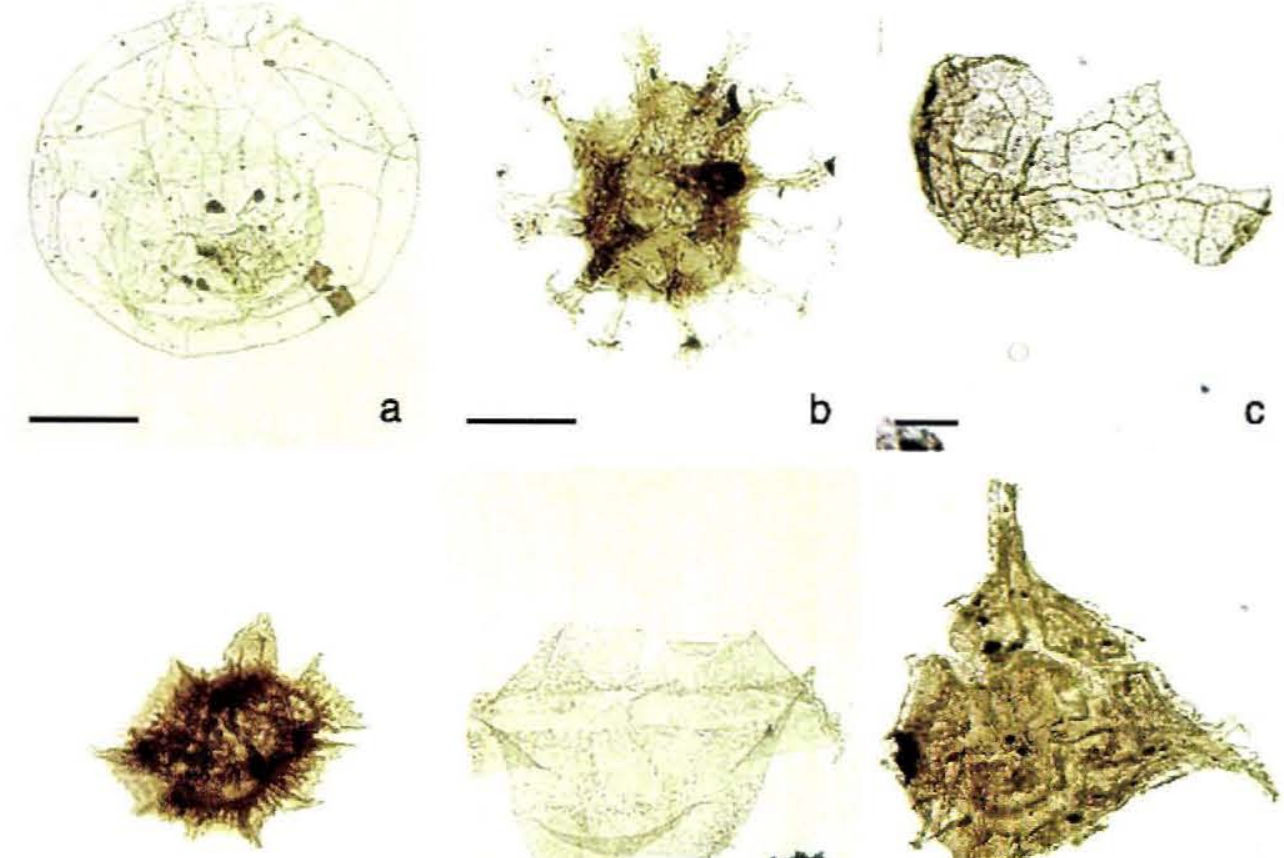

b ल
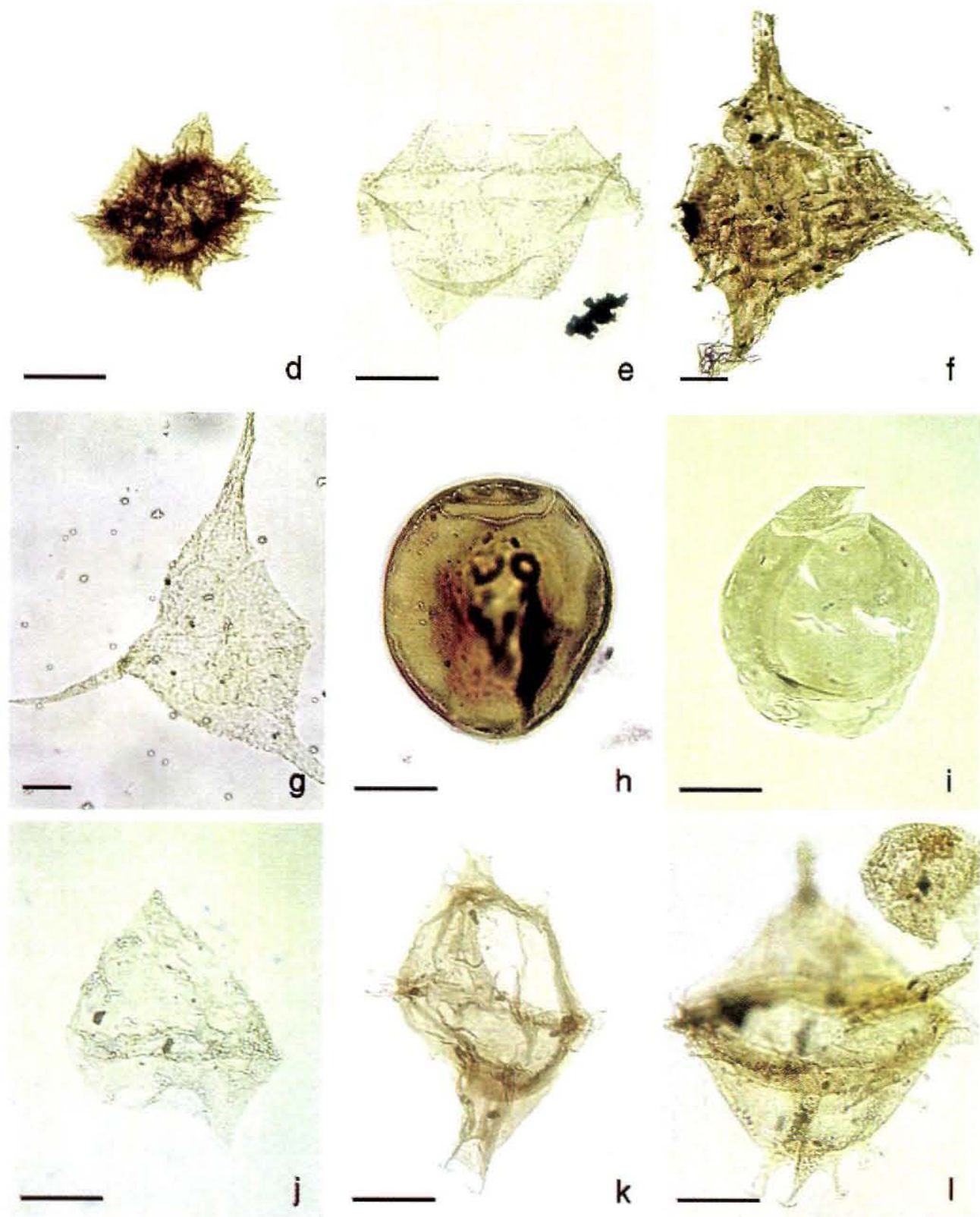

h

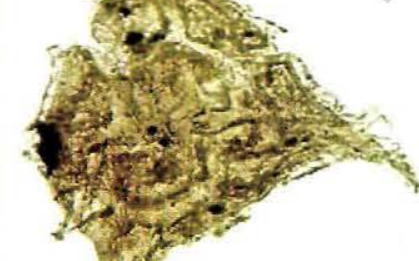


characteristics from East Greenland are comparable with those from Australia and Papua New Guinea.

Pseudoceratium anaphrissum, which is an important stratigraphic marker for the lower Barremian black shale facies in north-west Europe, Norway and East Greenland, is apparently absent in Arctic Canada and probably also in Eastern Canada. Batioladinium longicornutum is common in Hauterivian to Barremian deposits in north-west Europe, Norway and East Greenland but is very rare in Arctic Canada and not reported from Eastern Canada. Pseudoceratium nudum (Barremian to lower Aptian), which is common in East Greenland, Norway and Arctic Canada, is very rare in north-west Europe and apparently absent in eastern Canada. The species Pseudoceratium toveae (Barremian, Fig. $4 \mathrm{~g}$ ), recorded from East Greenland, offshore Norway and Arctic Canada (unpublished data 1989) has not been reported from north-west Europe, except offshore Norway. However, the closely related species Pseudoceratium weymouthense occurs in the uppermost Late Jurassic and lowermost Early Cretaceous in Australia.

Senoniasphaera microreticulata (upper? Aptian to middle Albian) has not been reported from north-west Europe or from the southern hemisphere, whereas it seems to be a good stratigraphical marker in offshore Norway, Arctic Canada and East Greenland. Pseudoceratium expolitum (middle to upper Albian) is also very rare in Europe except offshore Norway, Arctic and Eastern Canada and East Greenland where it is common and stratigraphically useful.

Chichaouadinium vestitum (middle to upper Albian) and Wigginsiella grandstandica (lower part of upper Albian, Fig. 41) have not been recorded from areas outside North America and East Greenland.

Ovoidinium? sp. 1 (Figs 4 h $\&$ i) has only been recorded from offshore Norway and East Greenland. It is common to very abundant in the uppermost Albian to lowermost Cenomanian.

The combined dominance of Rhombodella paucispinosa and Subtilisphaera kalaalliti (Fig. 4j) in upper Albian sediments in East Greenland seems to be a local phenomenon.

According to palaeogeographic maps of the Early Cretaceous of the North Atlantic region, land barriers having an influence on the mixing of Arctic and Boreal dinoflagellate cyst assemblages apparently did not exist. The geographically restricted occurrence of some of the species may therefore have been controlled by differences in salinity, temperature or local current patterns.

\section{Dinoflagellate cyst zonation in East Greenland}

The zonation is based on the ranges and acmes of 53 stratigraphically important species (Fig. 2). Five zones
(I-V) are erected, and subdivided into 13 subzones (Fig. 3). One zone and three subzones are distinguished in the Barremian, two zones and four subzones for the Aptian to Lower Albian, and two zones and six subzones for the Middle and Upper Albian. Each zone and subzone is defined by two lowest or highest occurrences of taxa.

Acknowledgements. The author wishes to thank the Carlsberg Foundation for financing the Ph.D. project and the Danish Research Academy for financial support during a six month stay at the Institute of Sedimentary and Petroleum Geology (I.S.P.G.), Geological Survey of Canada, Calgary, Canada.

\section{References}

Donovan, D. T. 1953: The Jurassic and Cretaceous stratigraphy and palaeontology of Traill $\emptyset$, East Greenland. Meddr Grønland 111(4), $150 \mathrm{pp}$.

Donovan, D. T. 1955: The stratigraphy of the Jurassic and Cretaceous rocks of Geographical Society $\varnothing$, East Greenland. Meddr Grønland 103(9), $60 \mathrm{pp}$.

Donovan, D. T. 1957: The Jurassic and Cretaceous systems in East Greenland. Meddr Grønland 155(4), 214 pp.

Donovan, D. T. 1972: Cretaceous system. In Callomon, J. H., Donovan, D. T. \& Trümpy, R. (ed.) An annotated map of the Permian and Mesozoic formations of East Greenland. Meddr Grønland 168(3), 21-24.

Lentin, J. K. \& Williams, G. L. 1989: Fossil dinoflagellates: index to genera and species, 1989 edition. Amer. Ass. strat. Palynol. Contr. Ser. 20, 473 pp.

Maync, W. 1949: The Cretaceous beds between Kuhn Island and Cape Franklin (Gauss Peninsula), northern East Greenland. Meddr Grønland 133(3), 291 pp.

Nøhr-Hansen, H. 1993: Dinoflagellate cyst stratigraphy of the Barremian to Albian, Lower Cretaceous, North-East Greenland. Bull. Gronlands geol. Unders. 166, 171 pp.

Spath, L. F. 1946: Preliminary notes on the Cretaceous ammonite faunas of East Greenland. Meddr Gronland 132(4), 11 pp.

Stemmerik, L., Christiansen, F. G., Piasecki, S., Jordt, B., Marcussen, C. \& Nøhr-Hansen, H. 1993: Depositional history and petroleum geology of the Carboniferous to Cretaceous sediments in the northern part of East Greenland. In Vorren, T. O. (ed.) Arctic geology and petroleum potential, 67-87. Amsterdam: Elsevier

Surlyk, F. 1990: Timing, style and sedimentary evolution of Late Palacozoic-Mesozoic extensional basins of East Greenland. In Hardman, R. F. P. \& Brooks, J. (ed.) Tectonic events responsible for Britain's oil and gas reserves. Spec. Publ. Geol. Soc. Lond. 55, 107-125.

H. N.-H., Geological Survey of Greenland, Copenhagen 